\section{References}

${ }^{1}$ Dollery CT, Paterson JW, Conolly ME. Clinical pharmacology of betareceptor-blocking drugs. Clin Pharmacol Ther 1969;10:765-99.

2 Donoso E, Cohn LJ, Newman BJ, Bloom HS, Stein WG, Friedberg CK. Effects of propranolol on patients with complete heart block and implanted pacemakers. Circulation $1967 ; 36$ :534-8.

${ }^{3}$ Michelakis AM, McAllister RG. The effect of chronic adrenergic receptor blockade on plasma renin activity in man. $f$ Clin Endocrinol Metab $1972 ; 34: 386-94$

${ }^{4}$ Lewis PJ. Propranolol-an antihypertensive drug with a central action. In: Davies DS, Reid JL, eds. Central actions of drugs in blood pressure regulation. London: Pitman, 1975.

${ }^{5}$ Frohlich ED, Tarazi RC, Dunstan HP, Page IH. The paradox of betaadrenergic blockade in hypertension. Circulation 1968;37:417-23.

${ }^{6}$ Tarazi RC, Dunstan HP. Beta adrenergic blockade in hypertension. Practical and theoretical implications of long term hemodynamic variations. Am $\mathcal{F}$ Cardiol $1972 ; 29: 633-40$.

7 Amery A, Billiet L, Boel A, Fagard R, Reybrouck T, Willems J. Mechanism of hypotensive effect during beta adrenergic blockade in hypertensive patients. Am Heart f 1976;91:634-42.

8 Prichard BNC, Gillam PMS. Treatment of hypertension with propranolol. Br Med 7 1969;i:7-16.

${ }^{9}$ Pollet RJ, Levey GS. Principles of membrane receptor physiology and their application to clinical medicine. Ann Int Med 1980;92:663-80.

${ }^{10}$ Durão V, Martins-Prata $M$, Gonçalves LMP. Modification of antihypertensive effect of $\beta$-adrenoceptor-blocking agents by inhibition of endogenous prostaglandin synthesis. Lancet 1977 ;ii:1005-7.

11 Vane JR. Inhibition of prostaglandin synthesis as a mechanism of action for aspirin-like drugs. Nature (New Biology) 1971 ;231:232-5.

12 Fichman M, Telfer N, Zia P, Speckart P, Golub M, Rude R. Role of prostaglandins in the pathogenesis of Barrter's syndrome. Am $\mathcal{F} \mathrm{Med}$ 1976;60:785-97.

13 Brash AR, Baillie TA, Clare RA, Diaffan GH. Quantitative determination of the major metabolite of prostaglandins $F_{1 \alpha}$ and $F_{2 \alpha}$ in human urine by stable isotope dilution and combined gas chromatography mass spectrometry. Biochem Med 1976;16:77-94.
14 Skellern GC, Salole EG. A high speed liquid chromatographic analysis of indomethacin in plasma. $\mathcal{F}$ Chromatogr $1975 ; 114: 483-5$.

15 MRC working party on mild to moderate hypertension. Randomised controlled trial of treatment for mild hypertension: design and pilot trial. $\mathrm{Br} \mathrm{Med} \mathcal{F} 1977$; : 1437-40.

16 Vane JR. The mode of action of aspirin and similar compounds. F Allergy Clin Immunol 1976;58:691-712.

17 Webster J, Hensby CN, Crowley K, Dollery CT. Circulating prostacyclin levels are increased by bendrofluazide in patients with essential hypertension. Proceedings of the 7 th scientific meeting of the international society of hypertension, 1980. New .Orleans: International Society of Hypertension 1980:142.

18 Usberti M, Mileti M, Maiorca R. Effect of indomethacin on renal function. Kidney Int 1975;7:197.

19 Freis ED. Salt in hypertension and the effects of diuretics. Annu Rev Pharmacol Toxicol 1979;19:13-23.

${ }^{20}$ Lee JB, McGiff JC, Kannegiesser H, Aykent YY, Mudd JG, Frawley TF. Prostaglandin $\mathrm{A}_{2}$ - antihypertensive and renal effects. Studies in patients with essential hypertension. Ann Int Med 1971;74:703-10.

21 Wennmalm $\AA$. Influence of indomethacin on the systemic and pulmonary vascular resistance in man. Clin Sci Mol Med 1978;54:141-5.

${ }^{22}$ Donker AJM, Arisz L, Brentjens JRH, Van der Hem GK, Hallemans HJG. The effect of indomethacin on kidney function and plasma renin activity in man. Nephron 1976;17:288-96.

${ }^{23}$ Patak RV, Basab K, Mookerjee BK, et al. Antagonism of the effects of furosemide by indomethacin in normal and hypertensive man. Prostaglandins $1975 ; 10: 649-59$.

24 Lopez-Overojo JA, Weber MA, Drayer JIM, Sealey JE, Laragh JH. Effects of indomethacin alone and during diuretic or beta-adrenoceptor blockade therapy on blood pressure and the renin system in essential hypertension. Clin Sci Mol Med 1978;55:203-5S.

25 Salvetti A, Pedrinelli R, Poli L, Sassano P, Arzilli F. The effect of indomethacin on plasma renin activity and aldosterone in essential hypertensive patients. Eur $\mathcal{F}$ Clin Invest 1978;8:340-1.

(Accepted 18 fuly 1980)

\title{
Chronic stable asthma and the normal arterial pressure of carbon dioxide in hypoxia
}

Guy's and Lewisham Health Districts

G M COCHRANE, MB, MRCP, consultant physician

Guy's Hospital Medical School, London SE1

J G PRIOR, MB, MRCP, Sir Philip Oppenheimer research fellow, department of medicine

C B WOLFF, PHD, MRCP, senior lecturer, department of physiology

\section{Introduction}

Patients with asthma often have an arterial carbon dioxide tension $\left(\mathrm{PaCO}_{2}\right)$ lower than the generally accepted normal value. The same patients, however, may be moderately or even severely hypoxic. We consider that a parallel should be drawn with normal subjects acclimatised to the hypoxia of altitude, in whom $\mathrm{PaCO}_{2}$ is reduced linearly with hypoxia. ${ }^{1}$ Patients with asthma may remain in a comparatively stable state with few symptoms and yet be hypoxic. If such patients respond to hypoxia in a similar fashion to normal subjects acclimatised to the hypoxia of high altitude they will also lower their $\mathrm{PaCO}_{2}$. In order to investigate this possibility we measured arterial oxygen tensions $\left(\mathrm{PaO}_{2}\right)$ and $\mathrm{PaCO}_{2}$ in patients with chronic stable asthma.

\section{Patients and methods}

Patients were prospectively selected for this study if they fulfilled five criteria. (1) They had a history of asthma since childhood; (2) peak expiratory flow rate or forced expiratory volume in one second increased by over $15 \%$ either spontaneously or after inhalation of $200 \mu \mathrm{g}$ isoprenaline sulphate; (3) skin-prick tests to two common allergens were positive and there was a history suggesting that symptoms increased on exposure to these allergens; (4) there was an excess of eosinophils in the sputum or blood, or both; and (5) no appreciable change in exercise tolerance, wheeze, or tightness of the chest had occurred in the preceding week. 
All patients had extrinsic asthma. We excluded those with clinical features suggesting chronic obstructive bronchitis. Most patients were studied at a routine follow-up asthma clinic; a few were studied on admission to hospital for investigation or treatment of chronic intractable asthma. Criteria for chronicity were based mainly on history and a normal arterial $\mathrm{pH}$. In a few patients peak expiratory flow rate was known to have been stable over the preceding week.

Arterial blood samples were obtained by percutaneous puncture of the non-dominant radial artery. Arterial blood was analysed for $\mathrm{pH}$, $\mathrm{PaO}_{2}$, and $\mathrm{PaCO}_{2}$ with an IL 213 blood-gas analyser. Calibrations for pH were made using standard buffers (N B S Washington) and for $\mathrm{PaCO}_{2}$ and $\mathrm{PaO}_{2}$ using known gas mixtures previously analysed with the Haldane apparatus. Patients were excluded from the study if their arterial $\mathrm{pH}$ was outside the range $7 \cdot 35-7 \cdot 46$, as this suggested that the asthma was not chronic. Peak expiratory flow rate was measured within a few minutes of arterial puncture.

\section{Results}

Twenty-nine patients with extrinsic asthma (21 men and eight women), whose ages ranged between 19 and 44 years, were included in the analysis. Peak expiratory flow rate varied between 100 and $490 \mathrm{l} / \mathrm{min}$. The table shows arterial blood-gas tensions, arterial $\mathrm{pH}$, and peak expiratory flow rate for each patient.

Arterial pressures of oxygen $\left(\mathrm{PaO}_{2}\right)$ and carbon dioxide $\left(\mathrm{PaCO}_{2}\right), p H$ values, and peak expiratory flow rate in patients with chronic stable asthma

\begin{tabular}{|c|c|c|c|c|c|}
\hline $\begin{array}{l}\text { Case } \\
\text { No }\end{array}$ & Sex & $\mathrm{pH}$ & $\begin{array}{l}\mathrm{PaO}_{2} \\
(\mathrm{kPa})\end{array}$ & $\underset{(\mathrm{kPa})}{\mathrm{PaCO}_{2}}$ & $\begin{array}{l}\text { Peak expiratory } \\
\text { flow rate }(1 / \mathrm{min})\end{array}$ \\
\hline \multicolumn{6}{|c|}{ Outpatients } \\
\hline $\begin{array}{r}1 \\
2 \\
3 \\
4 \\
5 \\
6 \\
7 \\
8 \\
9 \\
10 \\
11 \\
12 \\
13 \\
14 \\
15 \\
16 \\
17 \\
18 \\
19 \\
20 \\
21 \\
22\end{array}$ & $\begin{array}{l}M \\
M \\
F \\
M \\
M \\
M \\
M \\
M \\
M \\
M \\
M \\
F \\
M \\
M \\
M \\
M \\
M \\
M \\
M \\
M \\
F \\
F\end{array}$ & $\begin{array}{l}7 \cdot 43 \\
7 \cdot 44 \\
7 \cdot 42 \\
7 \cdot 38 \\
7 \cdot 14 \\
7 \cdot 42 \\
7 \cdot 41 \\
7 \cdot 43 \\
7 \cdot 40 \\
7 \cdot 42 \\
7 \cdot 41 \\
7 \cdot 41 \\
7 \cdot 44 \\
7 \cdot 46 \\
7 \cdot 44 \\
7 \cdot 43 \\
7 \cdot 40 \\
7 \cdot 44 \\
7 \cdot 41 \\
7 \cdot 41 \\
7 \cdot 43 \\
7 \cdot 42\end{array}$ & $\begin{array}{r}10.5 \\
8.5 \\
8.0 \\
8.5 \\
14.0 \\
10.9 \\
13.7 \\
11.6 \\
10.1 \\
10.5 \\
9.9 \\
13.6 \\
10.1 \\
8.4 \\
10.5 \\
12.7 \\
10.8 \\
11.2 \\
10.1 \\
8.4 \\
10.7 \\
12.3\end{array}$ & $\begin{array}{l}3 \cdot 7 \\
3 \cdot 9 \\
3 \cdot 6 \\
3 \cdot 6 \\
5 \cdot 1 \\
4 \cdot 7 \\
5 \cdot 1 \\
4 \cdot 8 \\
4 \cdot 4 \\
4 \cdot 8 \\
5 \cdot 1 \\
5 \cdot 3 \\
5 \cdot 2 \\
4 \cdot 1 \\
4 \cdot 5 \\
5 \cdot 1 \\
5 \cdot 1 \\
5 \cdot 1 \\
4 \cdot 7 \\
4 \cdot 4 \\
4 \cdot 9 \\
5 \cdot 1\end{array}$ & $\begin{array}{l}140 \\
110 \\
120 \\
140 \\
360 \\
400 \\
230 \\
240 \\
480 \\
160 \\
120 \\
420 \\
150 \\
280 \\
242 \\
490 \\
460 \\
460 \\
320 \\
300 \\
270\end{array}$ \\
\hline \multicolumn{6}{|c|}{ Inpatients } \\
\hline $\begin{array}{l}23^{*} \\
24^{*} \\
25 \\
26 \\
27 \\
28 \\
29 \\
30\end{array}$ & $\begin{array}{l}F \\
F \\
F \\
F \\
M \\
F \\
M \\
M\end{array}$ & $\begin{array}{l}7 \cdot 42 \\
7 \cdot 45 \\
7 \cdot 45 \\
7 \cdot 43 \\
7 \cdot 40 \\
7 \cdot 44 \\
7 \cdot 41 \\
7 \cdot 40\end{array}$ & $\begin{array}{r}10 \cdot 1 \\
8 \cdot 3 \\
6.7 \\
8 \cdot 0 \\
10 \cdot 0 \\
10 \cdot 7 \\
11 \cdot 7 \\
11 \cdot 1\end{array}$ & $\begin{array}{l}4 \cdot 5 \\
4 \cdot 4 \\
3 \cdot 6 \\
4 \cdot 1 \\
4 \cdot 5 \\
4 \cdot 4 \\
5 \cdot 2 \\
5 \cdot 1\end{array}$ & $\begin{array}{l}160 \\
100 \\
100 \\
200 \\
280 \\
180 \\
200\end{array}$ \\
\hline
\end{tabular}

*Values recorded in same patient during two separate admissions Mean arterial $\mathrm{pH}$ was $7.423 \mathrm{pH} ;$ mean peak expiratory flow rate $2541 / \mathrm{min}$.

Figure 1 shows the relation between $\mathrm{PaCO}_{2}$ and $\mathrm{PaO}_{2}$. The trend towards a lower $\mathrm{PaCO}_{2}$ accompanying a low $\mathrm{PaO}_{2}$ is highly significant $(p<0.001)$. The relation is: $\mathrm{PaCO}_{2}$ predicted $=0.23 \mathrm{PaO}_{2}+2.2 \mathrm{kPa}$ (or $\mathrm{PaCO}_{2}$ predicted $=0.23 \mathrm{PaO}_{2}+16 \cdot 6 \mathrm{~mm} \mathrm{Hg}$ ). This is not significantly different from the relation given by $\mathrm{Wolff}^{1}$ for normal subjects acclimatised to altitude hypoxia.

\section{Discussion}

Asthma is defined as reversible airflow obstruction. Despite considerable variation in the degree of obstruction, however, many patients maintain remarkably stable arterial blood-gas tensions. Often, despite improvement in peak expiratory flow rate after admission to hospital, the arterial blood-gas tensions fail to improve for several days. ${ }^{2}$ Rebuck and $\operatorname{Read}^{2}$ showed that the mechanism leading to the fall in $\mathrm{PaO}_{2}$ is only partially related to peak expiratory flow rate. Reduction in $\mathrm{PaO}_{2}$ is associated with plugging of small airways, leading to a shunt effect. ${ }^{2-4}$ Persistence of small-airway dysfunction, with associated hypoxia but few symptoms, is well documented in asthma. ${ }^{5}$

We studied arterial blood-gas tensions in patients with chronic stable asthma to investigate whether there is a relation between $\mathrm{PaO}_{2}$ and $\mathrm{PaCO}_{2}$ similar to that found in normal subjects

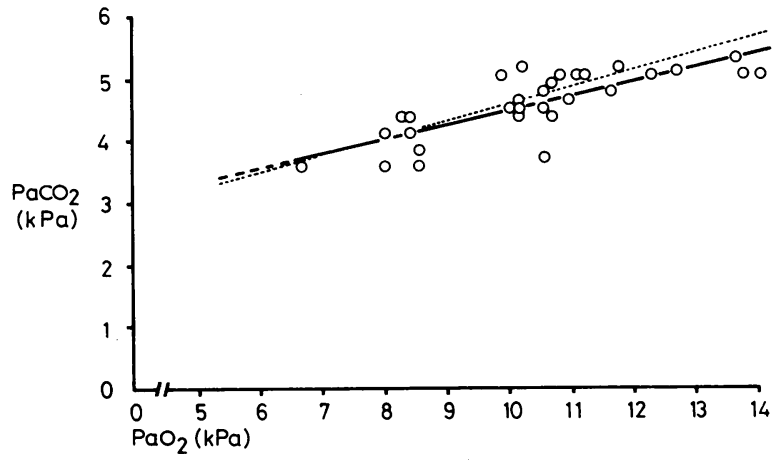

FIG 1 -Relation between $\mathrm{PaCO}_{2}$ and $\mathrm{PaO}_{2}$ in 29 patients with chronic stable asthma.

$\underline{-}=$ Least squares regression line. --- = Regression line extrapolated below $6.7 \mathrm{kPa}(50 \mathrm{~mm} \mathrm{Hg}) . \ldots$. Relation between $\mathrm{PaCO}_{2}$ and $\mathrm{PaO}_{2}$ calculated by Wolff ${ }^{1}$ for normal subjects acclimatised to altitude hypoxia.

Conversion: SI to traditional units- $\mathrm{PaCO}_{2}$ and $\mathrm{PaO}_{2}: 1 \mathrm{kPa} \approx 7.5$ $\mathrm{mm} \mathrm{Hg}$.

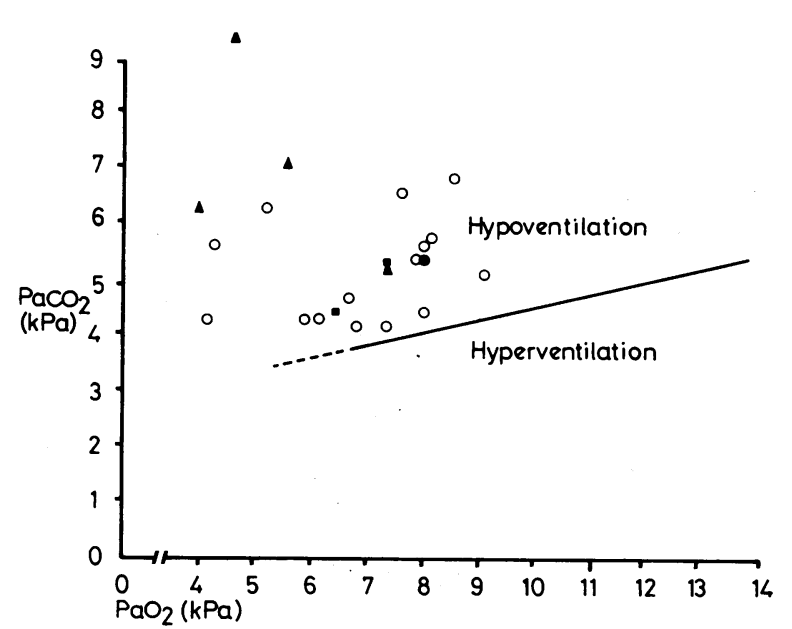

FIG 2-Relation of $\mathrm{PaCO}_{2}$ and $\mathrm{PaO}_{2}$ in patients with status asthmaticus (from Rees et $a l^{2}$ ). The line is the least squares regression line in our patients with chronic stable asthma (see fig 1). All the patients of Rees et al had $\mathrm{PaCO}_{2}$ values above the line, reflecting hypoventilation in relation to the ventilation expected from the degree of hypoxia.

$\mathrm{O}=$ Patients with $\mathrm{pH}$ value $7 \cdot 35-7 \cdot 46$. $\mathrm{a}=$ Patients with $\mathrm{pH}$ $>7 \cdot 46 . \Delta=$ Patients with $\mathrm{pH}<7 \cdot 35$. $\odot=$ Two patients at same point.

Conversion: SI to traditional units $-\mathrm{PaCO}_{2}$ and $\mathrm{PaO}_{2}: 1 \mathrm{kPa} \approx 7 \cdot 5$ $\mathrm{mm} \mathrm{Hg}$.

acclimatised to altitude hypoxia. An arterial $\mathrm{pH}$ within the range 7.35-7.46 was taken to indicate stability of the clinical condition, suggesting that the patient was neither acutely hypoventilating nor hyperventilating. The causes of the hypoxia in normal subjects at altitude and in patients with chronic stable asthma differ. In the normal subjects the arterial hypoxaemia is due to a low inspired oxygen concentration, whereas in our patients it resulted from a shunt effect. Despite the different mechanisms, the close similarity between the relations of $\mathrm{PaCO}_{2}$ to $\mathrm{PaO}_{2}$ in our patients and in normal subjects acclimatised to altitude hypoxia (fig 1) suggests that the ventilatory control system in patients 
with chronic stable asthma responds appropriately to hypoxia. We suggest that in the presence of chronic hypoxia the value of $\mathrm{PaCO}_{2}$ taken as "normal" should be that predicted by the relation of $\mathrm{PaCO}_{2}$ to $\mathrm{PaO}_{2}$ shown in figure 1-that is, a $\mathrm{PaCO}_{2}$ of $5.3 \mathrm{kPa}(40 \mathrm{~mm} \mathrm{Hg})$ would be normal if $\mathrm{PaO}_{2}$ were $13.3 \mathrm{kPa}$ $(100 \mathrm{~mm} \mathrm{Hg}$ ) but abnormally high and indicating hypoventilation if $\mathrm{PaO}_{2}$ were low. The "normal" $\mathrm{PaCO}_{2}$ would be $3.7 \mathrm{kPa}$ $(28 \mathrm{~mm} \mathrm{Hg})$ at a $\mathrm{PaO}_{2}$ of $6.7 \mathrm{kPa}(50 \mathrm{~mm} \mathrm{Hg})$.

We considered that patients who are severely ill from asthma might not show the acclimatisation response to hypoxia because respiratory control is abnormal or because of severe mechanical impairment to ventilation. Rees $e t a^{3}$ reported arterial blood-gas values for patients with status asthmaticus. We examined the relation of $\mathrm{PaCO}_{2}$ to $\mathrm{PaO}_{2}$ by plotting the values obtained in their patients on the day of admission (fig 2). In all patients $\mathrm{PaCO}_{2}$ was above the value predicted from our patients with chronic stable asthma. Many of the patients of Rees et al would already be regarded as severely ill on the basis of their arterial blood-gas and $\mathrm{pH}$ values. There remains a group with a $\mathrm{PaCO}_{2}$ of about $5.3 \mathrm{kPa}$ ( $40 \mathrm{~mm} \mathrm{Hg}$ ), however, in whom we suggest ventilatory control was impaired. These patients had therefore failed to adjust their ventilation normally, even though most of them had probably been severely ill and hypoxic for several days. ${ }^{6-8}$

In conclusion, we suggest that the relation between $\mathrm{PaCO}_{2}$ and $\mathrm{PaO}_{2}$ in patients with chronic stable asthma $\left(\mathrm{PaCO}_{2}\right.$ predicted $=$ $0.23 \mathrm{PaO}_{2}+2.2 \mathrm{kPa}$ (or $16.6 \mathrm{~mm} \mathrm{Hg}$ )) be adopted as a criterion for assessing adequacy of ventilatory control. Values of $\mathrm{PaCO}_{2}$ above this predicted normal indicate impaired ventilatory control and may give early warning of impending decompensa- tion in patients severely ill from asthma even when the arterial $\mathrm{pH}$ is normal.

We thank Professor T J H Clark for his help and encouragement with this study.

JGP was supported by the Sir Philip Oppenheimer Research Fellowship, department of medicine, Guy's Hospital.

GMC and CBW are in receipt of a MRC research grant.

Requests for reprints should be sent to Dr G M Cochrane, Department of Medicine, Respiratory Laboratory, 18th Floor, Guy's Tower, Guy's Hospital, London SE1 9RT.

\section{References}

1 Wolff CB. Normal respiration in chronic hypoxia. $\mathcal{F}$ Physiol 1980;308: 118-9P.

2 Rebuck AS, Read J. Assessment and management of severe asthma. $A m \mathcal{F}$ Med $1971 ; 51: 788-98$

${ }^{3}$ Rees HA, Millar JS, Donald KW. A study of the clinical course and arterial blood gas tension of patients in status asthmaticus. $Q \mathcal{F}$ Med $1968 ; 37: 541-61$.

${ }^{4}$ McFadden ER, Kiser R, DeGroot WJ. Acute bronchial asthma. $N$ Engl f Med 1973;288:221-5.

${ }^{5}$ Cochrane GM, Benatar SR, Davis J, Collins JV, Clark TJH. Correlation between tests of small airway function. Thorax 1974;29:172-8.

${ }^{6}$ MacDonald JB, MacDonald ET, Seaton A, Williams DA. Asthma deaths in Cardiff 1963-74: 53 deaths in hospital. Br Med $\mathcal{F}$ 1976;ii:721-3.

7 Bellamy D, Collins JV. "Acute" asthma in adults. Thorax 1979;34:36-9.

8 Ormerod LP, Stableforth DE. Asthma mortality in Birmingham 1975-77: 53 deaths. Br Med f 1980;280:687-90.

\title{
Changes in glycosylated haemoglobin after poor control in insulin-dependent diabetics
}

\author{
ANDREW P BROOKS, ISOBEL M NAIRN, JOYCE D BAIRD
}

\section{Summary and conclusions}

Glycosylated haemoglobin $\left(\mathrm{Hb}_{1}\right)$ was measured in seven insulin-dependent diabetic patients before, during, and after a seven-day period of monitored poor control. There was considerable individual variation in the pattern and degree of change in $\mathbf{H b A}_{1}$ concentration induced by poor control and the time when it occurred. Greater increases in $\mathbf{H b A}_{1}$ were seen during the period of metabolic derangement than in the subsequent two months.

More information is required before $\mathrm{HbA}_{1}$ estimations are widely used clinically to monitor control in individual diabetics.

\section{Introduction}

Concentrations of glycosylated haemoglobin $\left(\mathrm{HbA}_{1}\right)$ are raised in diabetic patients and, since the glucose linkage is considered

\footnotetext{
Metabolic Unit, University of Edinburgh, Department of Medicine, Western General Hospital, Edinburgh

ANDREW $\mathbf{P}$ BROOKS, MRCP, MD, lecturer in medicine (now senior registrar, Department of Medicine, Ipswich Hospital, Ipswich) ISOBEL M NAIRN, BSC, senior biochemist

JOYCE D BAIRD, MA, FRCP, senior lecturer in medicine
}

to be relatively stable, are thought to reflect the mean blood glucose concentration during the preceding one to two months. Hence $\mathrm{HbA}_{1}$ estimations are being used as a means of monitoring the degree of overall control of blood glucose achieved in individual diabetics. There are, however, many problems associated with measuring $\mathrm{HbA}_{1}$ and neither the time relation between changes in blood glucose and $\mathrm{HbA}_{1}$ concentrations nor the stability of $\mathrm{HbA}_{1}$ nor its sensitivity in detecting poor control has been clearly defined.

We compared two common methods of estimating $\mathrm{HbA}_{1}$ and examined the change in concentration of $\mathrm{HbA}_{1}$ resulting from a period of poor control deliberately induced in longstanding, insulin-treated diabetic patients maintained under strictly monitored, metabolic conditions.

\section{Patients and methods}

One male and six female diabetic patients being treated with insulin were studied (table I). All were fully ambulant, none was obese, and none had retinopathy, neuropathy, or nephropathy. All gave informed consent to the investigation.

The study covered 13 weeks and was divided into three periods. In the initial three-week assessment period patients were at home following their usual diet and insulin regimen and undertaking normal activity. They were visited each week on the morning after completing a 24-hour urine collection for measuring urinary glucose excretion, and fasting blood was taken for estimating whole blood true glucose, serum lipid, and $\mathrm{HbA}_{1}$ concentrations. 